University of Nebraska - Lincoln

DigitalCommons@University of Nebraska - Lincoln

\title{
The Frost-Moved Rubbles Of Jumbo Dome And Their Significance In The Pleistocene Chronology Of Alaska
}

Clyde Wahrhaftig

United States Geological Survey

Follow this and additional works at: https://digitalcommons.unl.edu/usgsstaffpub

Part of the Earth Sciences Commons

Wahrhaftig, Clyde, "The Frost-Moved Rubbles Of Jumbo Dome And Their Significance In The Pleistocene Chronology Of Alaska" (1949). USGS Staff -- Published Research. 501.

https://digitalcommons.unl.edu/usgsstaffpub/501

This Article is brought to you for free and open access by the US Geological Survey at DigitalCommons@University of Nebraska - Lincoln. It has been accepted for inclusion in USGS Staff -- Published Research by an authorized administrator of DigitalCommons@University of Nebraska - Lincoln. 


\title{
THE FROST-MOVED RUBBLES OF JUMBO DOME AND THEIR SIGNIFICANCE IN THE PLEISTOCENE CHRONOLOGY OF ALASKA ${ }^{x}$
}

\author{
CLYDE WAHRHAFTIG \\ United States Geological Survey
}

\begin{abstract}
Jumbo Dome, a prominent landmark on the north side of the Alaska Range, is a small body of intrusive andesite surrounded by schist and by poorly consolidated sediments of Tertiary age. Frost-moved rubbles, consisting of coarse andesite blocks, almost completely mantle the dome and have advanced outward from it across a gently sloping terrain for distances as much as $\mathrm{I} \frac{1}{4}$ miles. Several different periods of rubble development are recognized, based on the amount of vegetal covering of the deposits, the preservation of their surface forms, and their degree of erosion by fluvial processes. The rubbles are not now moving and are believed to have originated under the influence of an arctic climate in a manner analogous to rock glaciers. The difference in altitude between presently moving rock glaciers in this region and the rubble deposits of Jumbo Dome corresponds to the difference in altitude between present ice-filled cirques and the lowest cirques of the Wisconsin stage of glaciation. Reasons are given for believing that fluvial weathering and destruction of rock glaciers represent climates at least as mild as the present. On this basis five separate glacial episodes, separated by interglacial and interstadial epochs, are recognized.
\end{abstract}

\section{INTRODUCTION}

A unique assemblage of detrital deposits surrounding Jumbo Dome, a prominent landmark on the north side of the Alaska Range, offers the possibility of estak ishing a more complete Pleistocene chronology for Alaska than has been recognized heretofore. These detrital deposits are believed to have originated under the influence of arctic or glacial climatic conditions in a manner analogous to that of rock glaciers. The deposits were noted during the mapping of the Nenana coal field, a part of the Geological Survey program of mapping the coal resources of Alaska. Although the field party was in the neighborhood of Jumbo Dome for six weeks, only four days in August, 1947, were spent on and about the dome. The primary aim of the work was the determination of the stratigraphy and structure of the Tertiary rocks; consequently, the features described in this article were observed only in passing,

I Published by permission of the Director, U.S. Geological Survey. Manuscript received December I4, 1948 . and this paper reports a reconnaissance rather than a detailed investigation. In I948 the area was revisited for three days, one day of which was spent in the vicinity of Jumbo Dome. The detrital deposits, along with other geology, were plotted on trimetrogon aerial photographs taken by the United States Army Air Forces. Fortunately, the line of flight passed directly over Jumbo Dome, so that most of the contacts of critical importance were plotted on vertical photographs. The information plotted on the photographs was transferred to a topographic map of the Nenana coal field (U.S. General Land Office, I9r6; scale I : 3 I, 680, contour interval 50 feet). This map with slight alterations is the base for figures 2 and 3 .

Jumbo Dome is a prominent steepsided butte located in the foothill belt of the north flank of the Alaska Range, about 60 miles S. $30^{\circ} \mathrm{W}$. from Fairbanks, Alaska (fig. I). It rises to an altitude of 4,505 feet, I,500-2,500 feet above the surrounding low, rolling country. It has a summit.plateau covering an area of 
about 60 acres, above which rise a few gentle hills and rock ledges, $5^{0}-{ }_{50}$ feet high.

The northern foothill belt of the Alaska Range is $20-25$ miles wide and consists of subparallel east-trending ridges and valleys, crossed by a superposed north-flowing drainage emerging derlain for the most part by crystalline schists of Paleozoic and pre-Cambrian age and by intrusive rocks. A blanket of consolidated deposits of early Tertiary age once covered this foothill belt but is now preserved largely in the lowlands. However, the Nenana gravel-a conglomerate of middle Tertiary age - forms

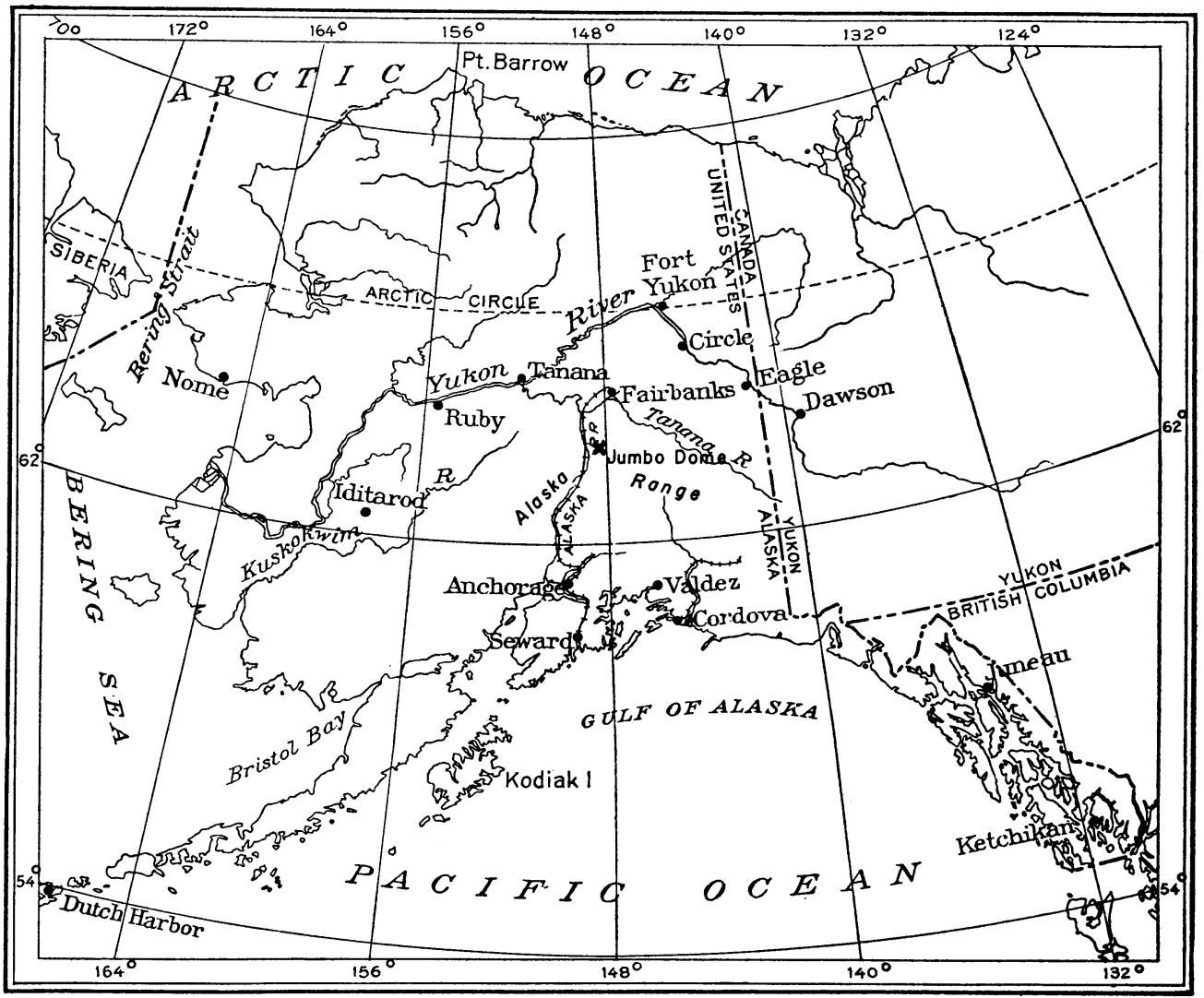

FIG. I.-Index map of Alaska, showing location of Jumbo Dome

from the Alaska Range. On leaving the foothill belt, the streams flow for distances of $20-50$ miles across an alluvial lowland called the Tanana Flats, before joining the Tanana River, a major tributary of the Yukon.

\section{GENERAL GEOLOGY}

The ridges of the foothill belt on the north flank of the Alaska Range are un- ridges and plateaus that rival in height some of the schist ridges. The regional geology has been described by Capps (I912; 1932, pp. 219-300; 1940, pp. 93I33).

Jumbo Dome is an intrusive mass of andesite, about I mile long in an eastwest direction (fig. 2) and about $\frac{3}{4}$ mile wide. Platy and linear flow structure are well developed in the andesite and indi- 


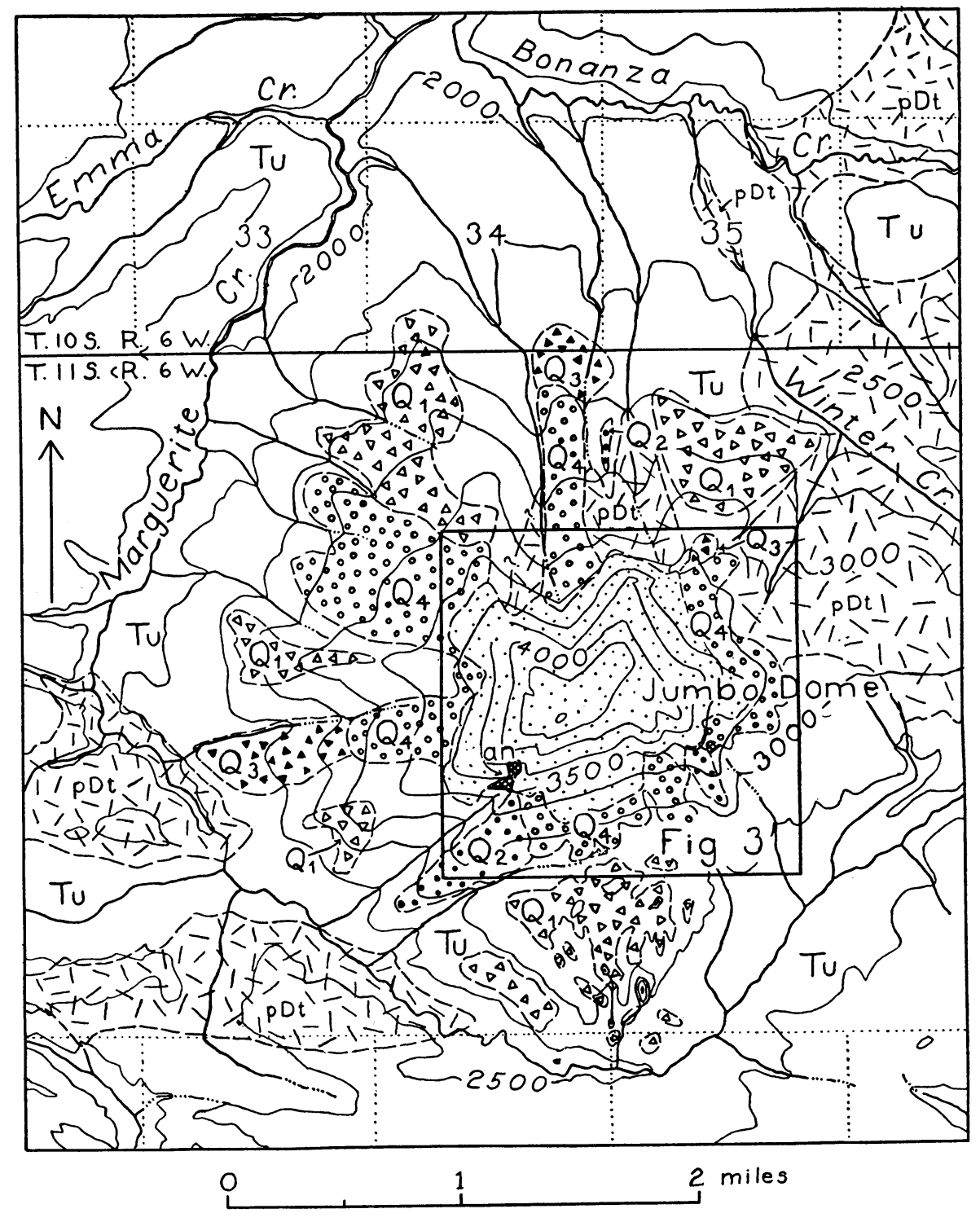

Contour interval 250 feet

EXPL ANATION

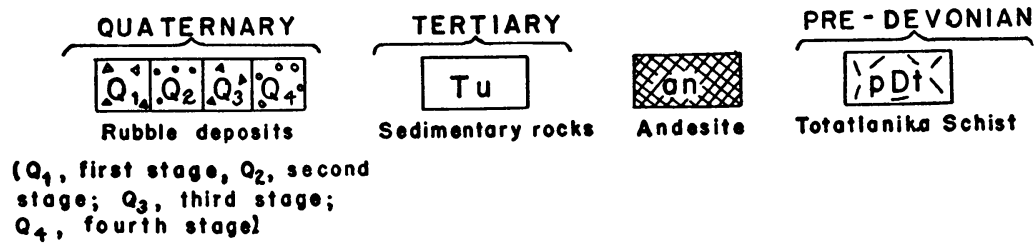

For geology of stippled oreo, seo fig. 3

FIG. 2.-Geologic map of Jumbo Dome and vicinity, Alaska 
cate that its intrusive contact with the crystalline schists dips steeply inward beneath the andesite, at angles of more than $45^{\circ}$. The mass of schists on the north and east flanks of the mountain is thought by Capps (I9I 2, p. 25) to be Paleozoic. If so, then the intrusion is Paleozoic or younger; it is quite definitely pre-Tertiary.

Tertiary coal-bearing deposits, consisting of poorly consolidated sandstone and shale, with interbedded sub-bituminous coal beds as much as 30 feet thick, border the andesite on the west and south. As exposed in gullies on the southeast and southwest sides of the mountain, the contact between coal-bearing rocks and andesite dips $70^{\circ} \mathrm{N}$. It is apparently a fault contact, for the coalbearing formation is not baked or altered along the contact and the rank of the coal appears unchanged. The coal-bearing rocks are folded into a tight anticline immediately adjacent to the fault, but they flatten to the south, and less than a mile from the south side of the mountain they are flat-lying. On the west and north sides of the mountain, where the Tertiary rocks dip away from the mountain at low angles, the contact between the andesite and Tertiary rocks was not seen. It is presumed that the Tertiary rocks were deposited unconformably on the andesite, as similar and related bodies of igneous rocks farther east are clearly overlain unconformably by coalbearing rocks of Tertiary age. However, no pebbles of the andesite of Jumbo Dome have been found in the coal-bearing rocks.

Following the deposition of the Tertiary sediments, the region was folded into gentle east-trending anticlines and synclines. Deformation of the rocks underlying the Tertiary deposits was by shearing along pre-existing planes of weakness.
The andesite of Jumbo Dome apparently was forced upward as a roughly cylindrical-shaped mass to a vertical height of I, 500 feet above the base of the surrounding Tertiary rocks. The movement appears to have been along a circular fault zone that in part coincided closely with the steeply dipping intrusive contact of the andesite and in part was the upward continuation of this roughly cylindrical surface into the overlying Tertiary rocks. The uncertainties regarding the structure of the area do not affect the problems here considered. The only important point is that the nearly equidimensional mass of andesite is separated from the surrounding rocks by nearly vertical contacts.

\section{GLACIATION}

Jumbo Dome lies IO-I 5 miles north of the northern limit of Wisconsin glaciation in the Alaska Range. A terminal moraine in the valley of the Nenana River, tentatively identified as Wisconsin in age (Capps, 1932, pp. 289-29r), is found about I 2 miles southwest of Jumbo Dome, near the town of Healy, at an altitude of $\mathrm{I}, 650$ feet. The lower limit of glacier accumulation of the Wisconsin stage, as indicated by the lowest cirques, differs considerably from place to place within the Alaska Range. In the vicinity of Mt. McKinley, 95 miles to the southwest of Jumbo Dome, it is about 4,5005,000 feet. On the south side of the range it is even lower. It appears to rise sharply northward across the range, because of the falling-off of precipitation (Capps, I940, p. I 54), and in the vicinity of Jumbo Dome it is doubtful whether mountains lower than 6,000 feet supported glaciers at any time during Wisconsin time. At present the lowest mountains on the north side of the Alaska Range which have cirques that contain gla- 
ciers are about 7,200 feet in altitude. Thus the lowering of the orographic snowline was about $\mathrm{r}, 200$ feet in Wisconsin time and probably more during earlier glaciations. Jumbo Dome $(4,5 \circ 5$ feet) lay below the lower limit of accumulation of ice in Wisconsin time.

Morainal deposits and erratics of a stage of glaciation earlier and of greater extent than the Wisconsin have been recognized in this area (Capps, I931, p. 7). The earlier glaciers apparently advanced northward across a now almost completely destroyed surface having a present altitude of about 4,000 feet in the vicinity of Jumbo Dome (Wahrhaftig, I946, pp. I34-135). All the rubble deposits described in this paper are found on topography which has been cut into this surface and are therefore younger than the earlier stage of glaciation.

\section{DESCRIPTION OF THE RUBBLE DEPOSITS}

The rubble deposits which surround Jumbo Dome consist of blocks of andesite that originated on the steep slopes of Jumbo Dome and extend outward across the surrounding schists and Tertiary sedimentary rocks as far as $\mathrm{I} \frac{1}{4}$ miles from the base of the dome. Some of the masses of rubble moved outward across an eroded surface on slopes much less than I $5^{\circ}$. Rubble deposits of several ages can be distinguished by their relative degrees of weathering and dissection. In all, five ages of rubble have been recognized. It is likely that more ages could be recognized, but adequate criteria for their distinction were not found. As will be brought out more fully later, in a section dealing with the influence of climate on denudation in the Alaska Range, it is the thesis of this paper that each rubble deposit near Jumbo Dome was formed under the arctic climate of a glacial stage or substage and then later weathered and dissected during a milder interglacial or interstadial episode.

The rubble deposits of Jumbo Dome resemble rock glaciers in many respects and probably originated in a somewhat similar fashion. The term "rock glacier" was first applied by Capps (I910, p. 360) to tonguelike masses of coarse debris in the Wrangell Mountains of Alaska, which he believed moved with a glacierlike motion. Deposits resembling these in part were called "rock streams" by Howe (I909) and "moving talus" by Bretz (I935, p. I92). Rock glaciers which have been described in the literature are large, commonly tonguelike masses of very coarse angular debris which extend down gentle slopes from the base of the cliffs or talus slopes from which their constituent fragments were derived. They are commonly 20-200 feet thick, the thickness being greatest at the lower end. Typical modern and recent rock glaciers, such as those described by Capps, Howe, Chaix (I923, pp. I-38), and Kesseli (I94I, pp.203-227), have steep fronts and sides and bear on their upper surface a series of parallel looped ridges, which are also parallel to the sides and front of the rock glacier.

The rock glaciers heretofore described are characteristically valley features, forming in cirques, and do not commonly originate on smooth slopes or form as continuous sheets, as are shown in figure 5, $A$. However, other rubble deposits of Jumbo Dome, which lie in a canyon on the north side of the mountain (see fig. 2) resemble in every respect rock glaciers described by Capps. In some respects the rubbles of Jumbo Dome have many features in common with the solifluction sheets and lobes recently described by A. L. Washburn (1947, pp. 86-96, pls. 23, 24) from Victoria Island. 
It is not the major purpose of this paper to discuss whether or not the rubbles of Jumbo Dome should be considered rock glaciers or solifluction sheets. However, some concept of the mode of origin of rock glaciers is necessary to an appreciation of the climatic factors involved in the formation of the rubbles. The first description of forms similar to rock glaciers was made by J. G. Andersson in I906 (pp. 9I-II2). He ascribed them to solifluction and assumed that they had originally been composed largely of fine debris, which was later removed. In rgro Howe published a paper on the landslides of the San Juan Mountains. He described many rock glaciers, under the name "rock streams," and ascribed to them a landslide origin. Evidence presented by Capps (I9Io, pp. 371-375), Patton (I9Io), Tyrrell (I9Io, pp. 550-55I), Chaix (1923, pp. ro-19), and ${ }_{1}$ Kesseli (I94I, pp. 210-215) shows clearly that they are not the work of landslides. Capps and Moffit (Igri, p. $\left.{ }_{56} 6\right)$ believe that rock-glacier movement proceeds in a glacier-like way and is due to movement of interstitial ice, although no doubt all true glacial ice has disappeared. Chaix and Kesseli expressed the opinion that they originate in the waning stages of glaciation as the ground moraine of an overloaded and enfeebled glacier and that they continue their motion by some process of frost heaving or solifluction after true glaciers have disappeared from the region. Chaix measured the rate of movement of some rock glaciers in Switzerland and found it to amount to more than I meter per year. Tyrrell, on the other hand, holds, with Patton and Howe, that their origin is not solely through glaciation. He cites as example a rock glacier on the outskirts of the city of Dawson, Yukon Territory, outside the region of continental glacia- tion. This rock glacier rises at the base of a cliff of greenstone, from which a spring emerges. In the winter this spring fills the rock glacier with a mass of ice, and it is to movement induced or aided by this ice that Tyrrell ascribes the advance of the mass of greenstone blocks over gentle terrain. The general appearance of the younger of the rubble deposits, as described below, indicates that they have moved in a manner closely similar to that of rock glaciers; yet their existence outside the limits of glaciation and on a mountain below the lower limit of the accumulation of Wisconsin time indicates that they have an origin independent of true glaciers.

\section{MODERN TALUS, FROST FORMS, AND THE YOUNGEST RUBBLE DEPOSITS \\ (FIFTH STAGE)}

With the exception of a few outcrops, the steep slopes of Jumbo Dome are entirely mantled with sheets of detritus (fig. 3). This detritus consists of angular blocks of andesite, equidimensional or slablike in form, averaging 2-4 feet in diameter, and ranging up to ${ }_{5}$ feet in greatest diameter. These sheets of coarse detritus are derived from the underlying rock by strong frost action and move down slopes partly by rolling and slipping and partly by creep due to freezing of interstitial water. They resemble the incipient forms of rock glaciers.

Most of the rock fragments or blocks are covered with a mantle of dark lichen on all exposed surfaces, whereas bottom surfaces or those in contact with other boulders are bare. The general aspect of the slopes is therefore very dark, almost black. According to H. M. Raup ${ }^{2}$ the development of such a lichen cover requires at least two hundred years, the minimum

\footnotetext{
2 Personal communication.
} 


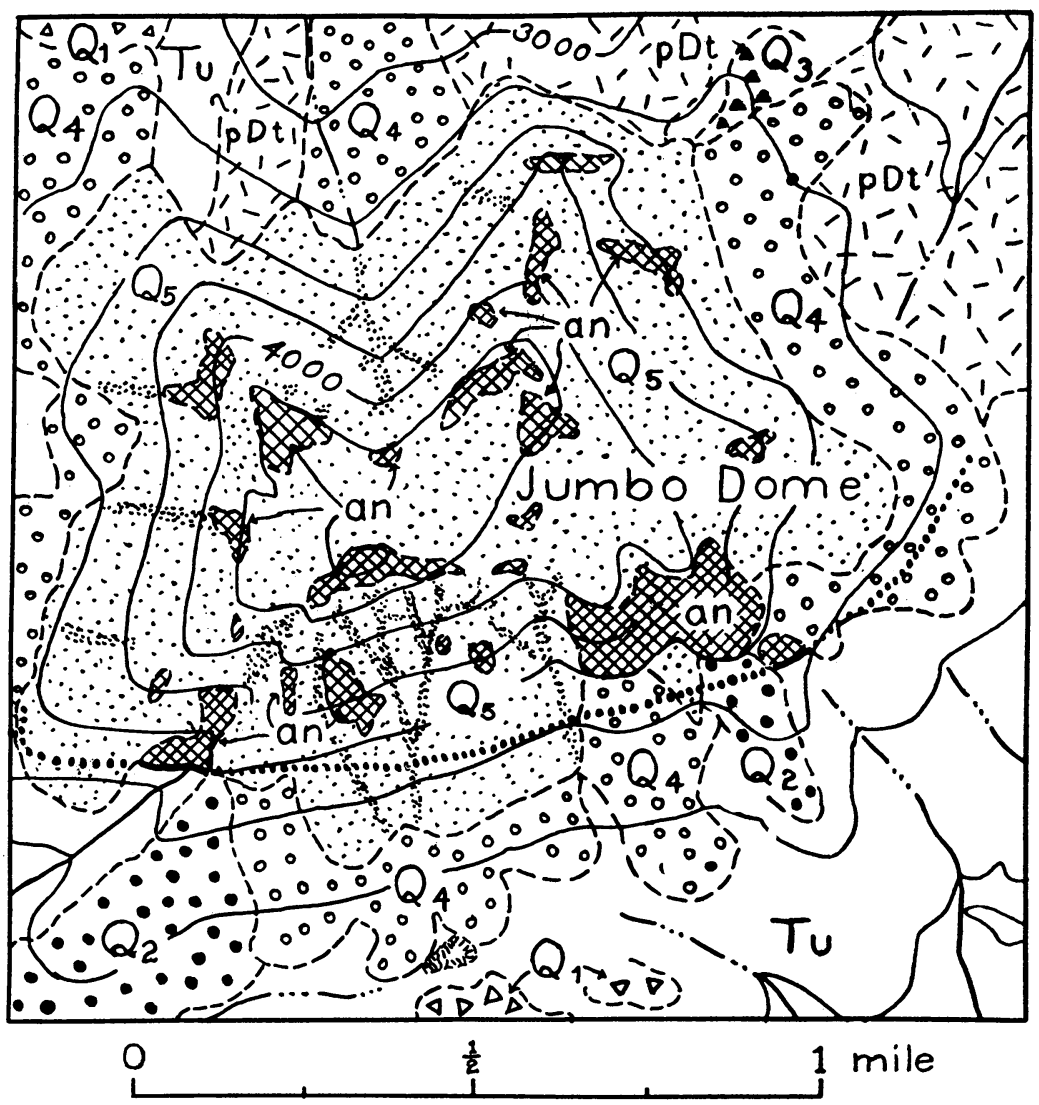

EXPLANATION

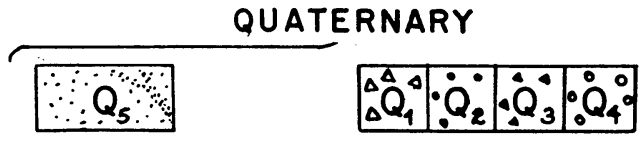

Detrital sheets, talus and youngest rubble deposits. (Active area indicated by closely spaced stipplingl

TER TIARY

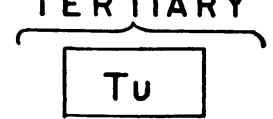

Sedimentary
Rubble deposits $\left(Q_{1}\right.$, first itage; $Q_{2}$, (dotted where second stage; $Q_{3}$, concealed) third stage; $Q_{4}$, furth stage)

\section{PRE - DEV ONIAN}

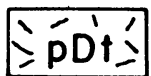

Totatlaniko Schist rocks 
period for which the sheets of lichen-covered rock fragments have been stable.

The fragments of a few areas are blocks of fresh andesite, having a light pink color. Presumably, the movement of blocks in these places is active (pl. I, $B$ ). The limited areas of active movement are located (I) below areas of exposed bedrock from which newly frost-riven blocks fall or move down slopes; (2) in places where the average grain size of the detrital sheet is less than 4 inches and some fine material is present; (3) on steep detrital cones where meltwater runs off, forming torrent levees. These detrital cones usually occur below reentrants and amphitheaters in the higher slopes. The torrent levees, which are double parallel ridges of boulders, lead downstream from the re-entrants. At the lower ends of the to:rent levees, the groove between them commonly passes into a steep-walled stream channel, the bottom of which is Io or I 2 feet below the surrounding slope. The torrent levees and the channels which extend down the slope from their lower ends are due to the action of meltwater in the spring and probably of summer cloudbursts. Water can be heard running beneath the grooves between the torrent levees, and the channels downslope from them have a small flow of water at the surface during most of the summer. Forms of somewhat similar appearance, described by Sharp (1942, pp. 222-227) from the Saint Elias Range, end in masses of bouldery mud and are apparently levees of alpine mudflows. Matthes (I930, pp. I08-109) has described similar forms from Yosemite Valley and attributes them to torrent action. The form and nature of the active talus deposits, involving as they do finer debris and running water, are not suggestive of an arctic or glacial climate as are the forms described in the following paragraphs.

In the upper part of the south face of the mountain a series of narrow horizontal curving bands of fresh blocks suggests a slight amount of movement en masse of the detrital sheet (pl. I, $B$ ), which is probably an incipient rock glacier. The undisturbed and lichen-covered nature of the greater part of the blockcovered slope indicates that the movement has affected only a small portion of the slope.

Differential movement of parts of the detrital sheet on the east side of the mountain is shown by lobelike masses of blocks, about 60 feet long down the slope, 20-40 feet wide, and rising 3-5 feet above the slope. The platy or flatter rock fragments are characteristically imbricated and dip upslope in the central parts of the lobes. Along the sides of the lobes they are oriented parallel to the direction of slope and dip inward beneath the lobe. Along the front of the lobe they are oriented parallel to the contour lines and dip beneath the lobe. The boulders of these lobes are lichen-covered and, therefore, have probably been more or less stable for at least two hundred years. However, rock glaciers have been observed where the boulders are lichencovered but where overturned trees, still living, show that some movement still continues. $^{3}$

The detrital sheet on the north slope of the northeast corner of Jumbo Dome has a series of low transverse ridges of detritus which have the appearance, seen from a distance, of gigantic ripple marks. The ridges are about roo feet apart, from crest to crest, and appear to pitch $30^{\circ}-45^{\circ}$ to the west, down the slope (fig. 4). The ridges were not examined close at hand,

\footnotetext{
${ }^{3} \mathrm{~S}$. R. Capps, personal communication.
} 
and their height above the slope is not known. They are made of the same coarse debris that makes up the detrital sheet. Each of them terminates upward both sharply and at a uniform level. The process of their formation is not known, but it is believed that intense frost action, of the type that produces the lobelike masses on the east slope, is the major agent. The detrital sheet on which the ridges are found is dark colored and is probably covered with lichen, although other plants are probably scarce or absent. The ripple-like ridges probably were formed at the same time as the lobelike masses on the east side of the mountain.

From the base of the steep detrital sheet on the northwest slope of the mountain, well-developed masses of rubble which resemble rock glaciers have advanced over older rubble deposits on a slope of less than $15^{\circ}$. These rubble deposits extend down to an altitude of 3,300 feet and are thickest at their lower ends. They are differentiated from older rubbles by the absence of fine detritus at the surface and by the absence of any plant life other than lichens on them. They rise above older rubbles with a steep slope. A side view of a typical mass of the youngest rubble (fifth stage) advancing over older rubbles is shown in plate $2, A$. The size and shape of this deposit of rubble resembles in many respects an incipient rock glacier, although it does not occur in a cirque. The presence of lichen on the boulders of these youngest rubbles suggests that they have been more or less stable for two hundred years and were formed in a very recent epoch of more rigorous climate.

RUBBLE DEPOSITS OF THE FOURTH STAGE

The youngest rubbles (fifth stage) rest on older rubble derived from Jumbo Dome. Like the younger rubbles, the older deposits consist largely of angular blocks of andesite, but a considerable admixture of fine materials derived from the weathering of andesite blocks is also present. This older rubble was carried downslope in a manner resembling the movement of rock glaciers and is attributed to the fourth recognizable stage of rubble movement on the mountain.

Rubble of the fourth stage can be distinguished from the youngest rubbles and detrital sheets by the degree of weathering it has undergone and by its cover of vegetation, which the rubble deposits of the fifth stage lack. That this difference in vegetative cover is the result of recency of movement of the youngest rubbles and not of altitudinal changes is demonstrated by the fact that the flat upper surface of Jumbo Dome bears a luxuriant tundra-type vegetation. On the surface of rubble deposits of the fourth stage are numerous patches of poorly to well-developed polygonal soils: stone rings, isolated silt patches, and stone stripes. ${ }^{4}$ Where these are present, there is no vegetation. These modern frost phenomena are thought to develop on top of the older rubble deposits and to represent the extent of present-day frost modification. Many of the andesite blocks have been split by frost action

${ }_{4}^{4}$ For definition of these terms see Sharp (1942b).

PLATE 1

$A$, View of Jumbo Dome from the south.

$B$, South face of Jumbo Dome, from hill of first-period rubble to the south. Active areas on the detrituscovered slope are light; stabilized, lichen-covered areas are dark. Note horizontal bands of incipient rockglacier movement near $A$. 


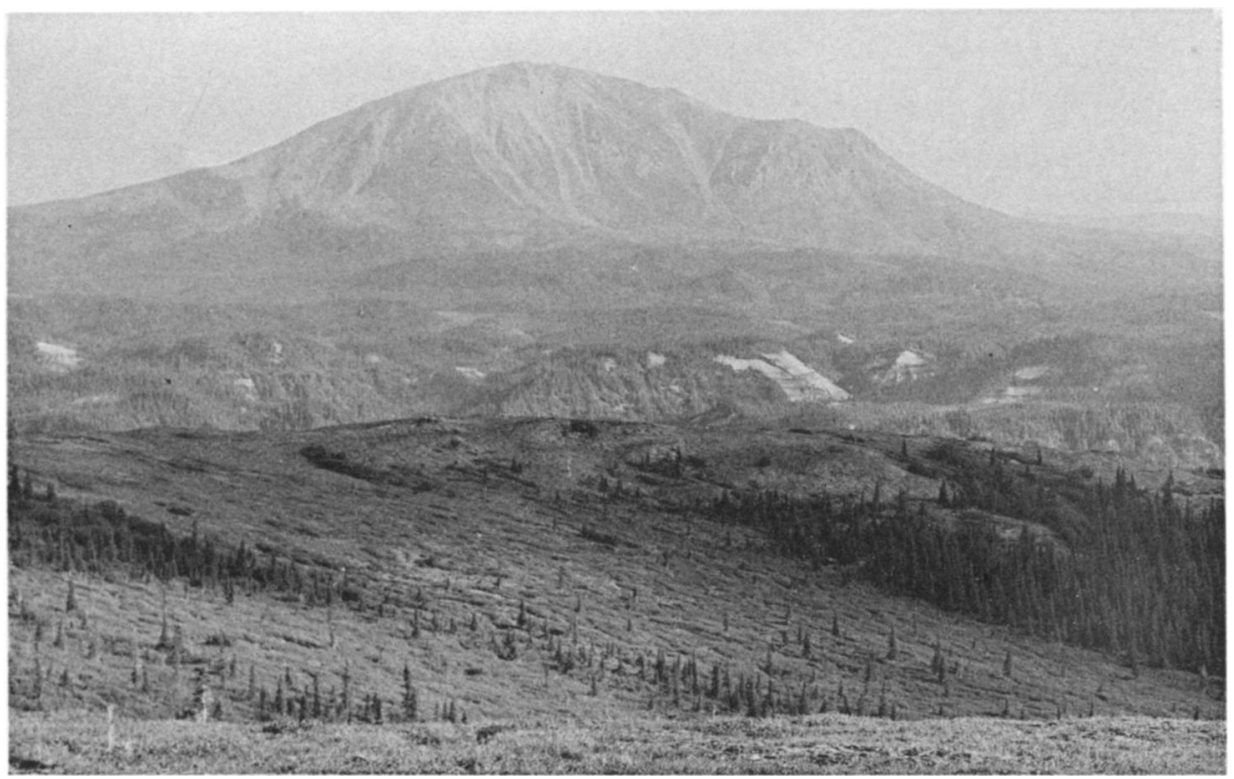

A

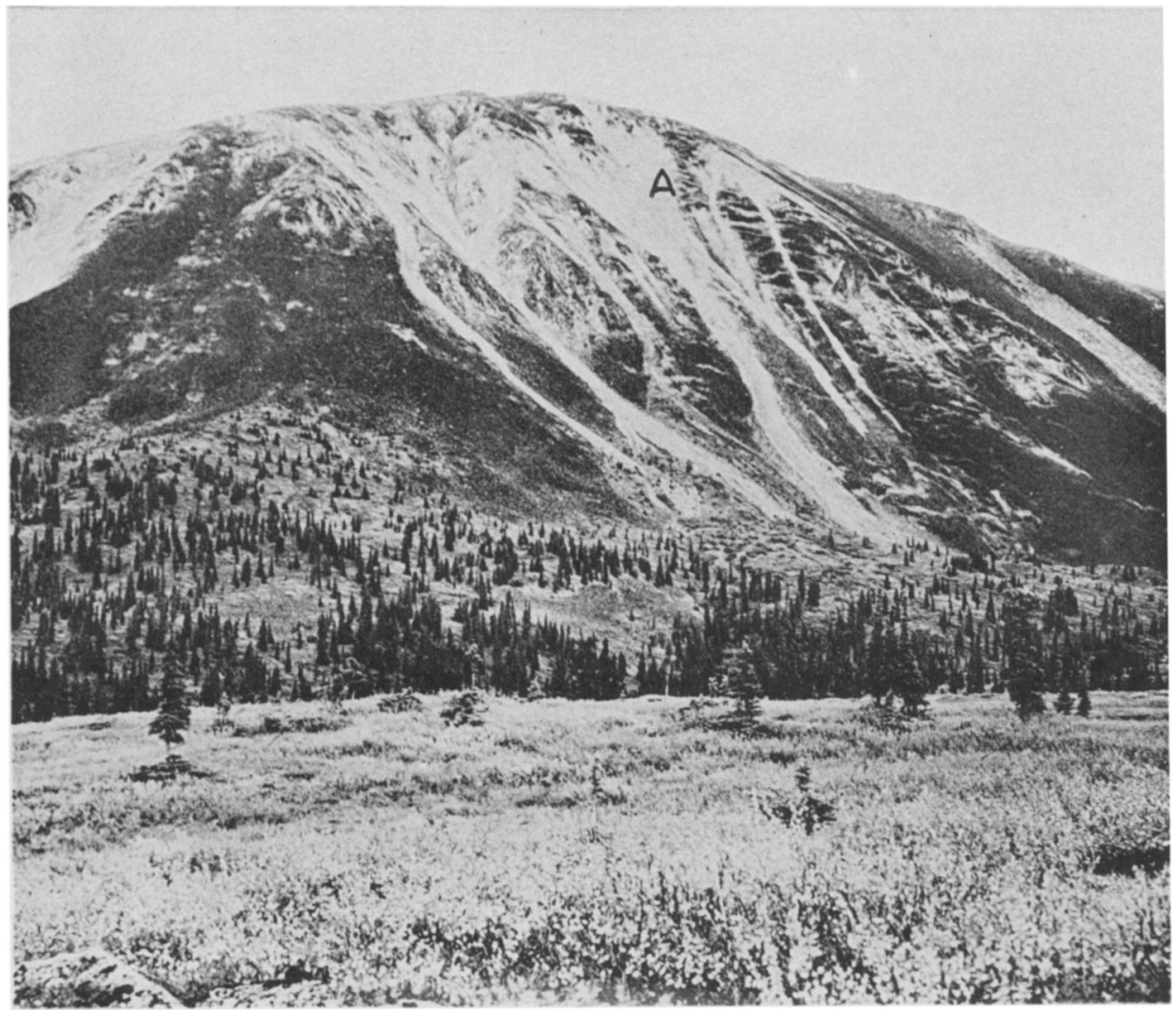

B 


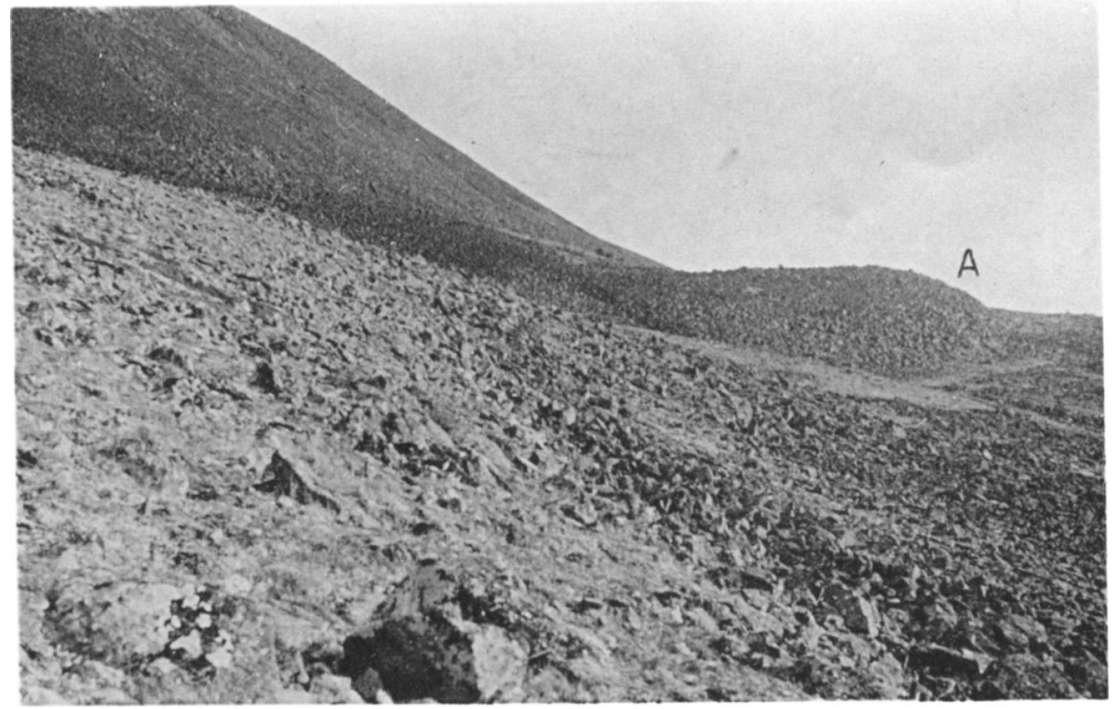

A

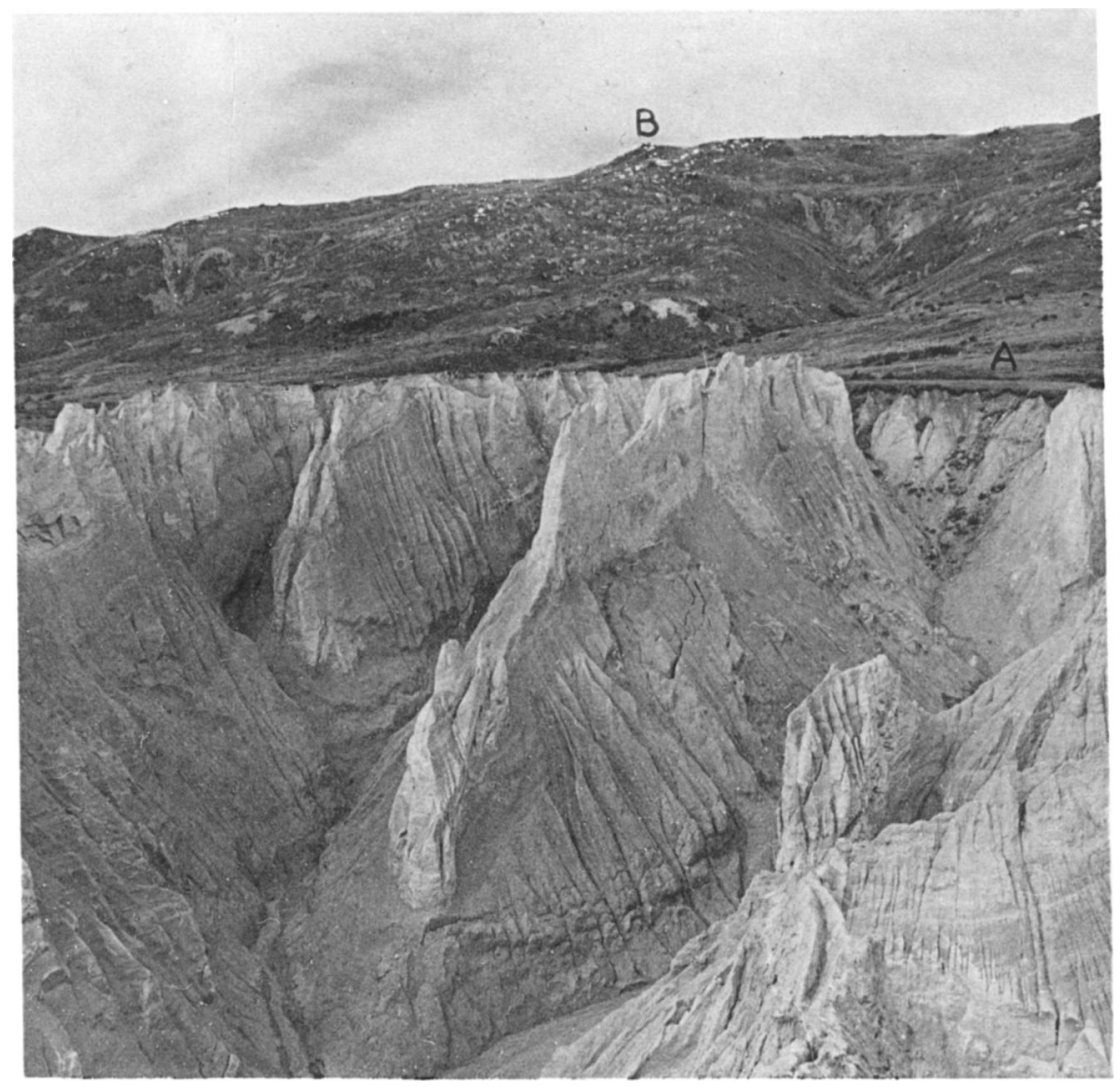

B

Rubble deposits and badlands 
into smaller fragments, which remain in the positions that they had in the original block, although spread by cracks I -3 inches wide. All exposed surfaces of these fragments, including the walls of the cracks, are covered by a thick coat of black lichens, as are all other blocks on the rubbles of the fourth stage. This ridges, which are brought out by unequal growth of vegetation on the ridges and in the intervening depressions. They (I) have distinct frontal slopes, which are usually modified somewhat by creep; (2) display convex upper surfaces; and (3) resemble rock glaciers. In general, they appear relatively little affected by

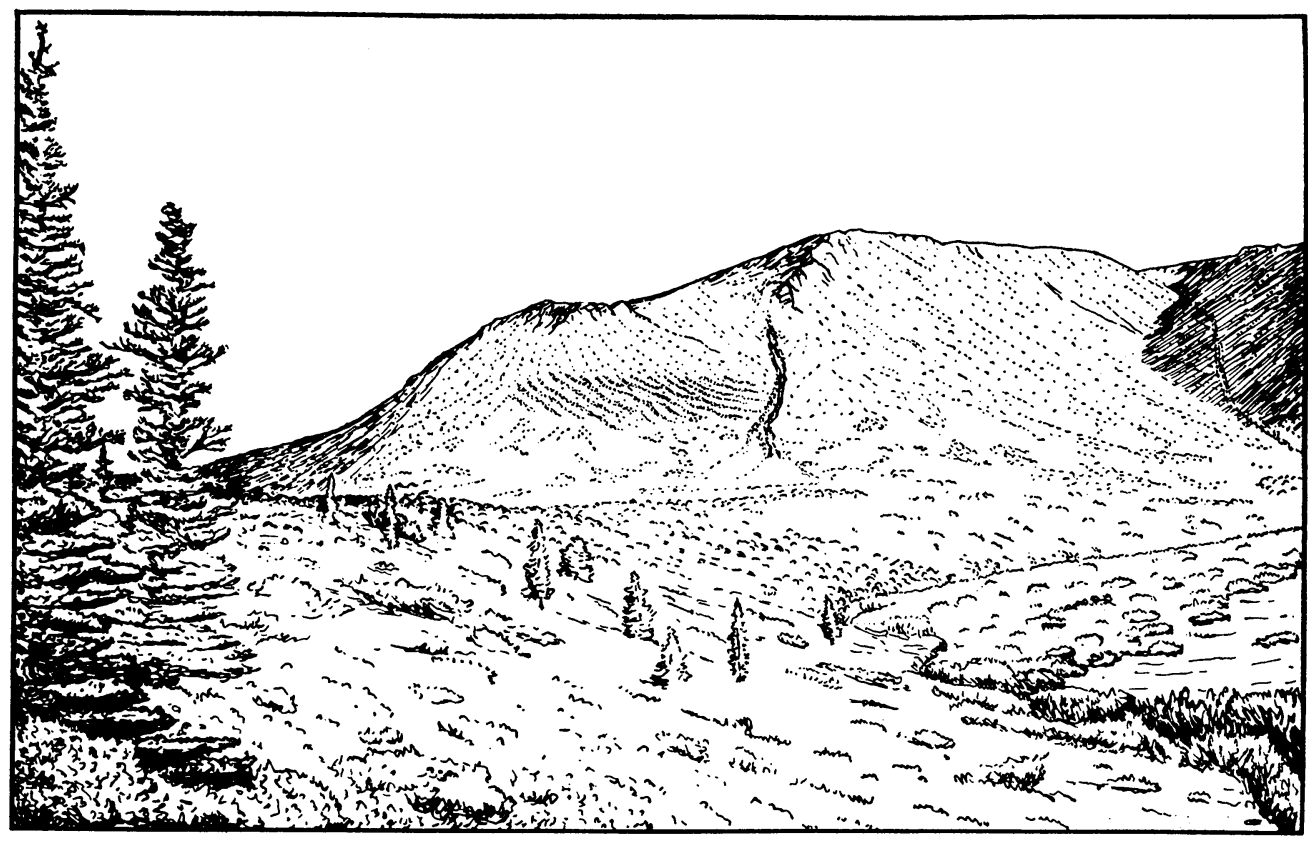

FIg. 4.-View of Jumbo Dome from the north (sketched from a photograph). Ripple-like frost forms can be seen immediately below the left-hand point of rock in the background; to the right of these is a small gully lined with torrent levees.

frost-splitting is the modification of the fourth-stage rubbles which formed during the development of the fifth-stage rubbles.

In general, rubble deposits of the fourth stage have well-preserved looped subsequent stream erosion, although in a few places they are channeled by gullies I 5 feet deep. The largest rubble deposits of the fourth stage are found on the north and west sides of the mountain, where they extend down valleys to an altitude

\section{PLATE 2}

$A$, Toe of rubble deposit, probably a rock glacier, of the youngest (fifth) stage ( $A$ in photograph), resting on older frost-moved rubble, at northwest corner of Jumbo Dome, from the north. Rubble of fourth stage in foreground.

$B$, Badland area in basal Tertiary conglomerate at head of McAdam Creek, 4 miles northeast of Jumbo Dome. The gentle surface in the middle background ( $A$ in photograph) is underlain by 20 feet of solifluction debris derived from the mountains of Totatlanika schist $(B)$ in the far background. 
of 2,500 feet, to about 700-800 feet below the lower limit of rubble deposits of the youngest (fifth) stage.

RUBBLE DEPOSITS OF THE THIRD STAGE

Angular andesite boulders cover the floors of valleys draining Jumbo Dome on the north and west from an altitude of about 2,250 feet upstream to the lower ends of the rubble deposits of the fourth stage. These masses of angular debris have no topographic expression, such as is shown by the younger rubble deposits. They do not rise above their surroundings but merge with them. However, as these sheets and masses of coarse debris consist of andesite blocks which have been carried 2,500-6,000 feet horizontally and 500-r,200 feet vertically below the contact between the andesite and sandstone, it is presumed that they were once rock glaciers or some related type of deposit which owed its movement to processes active under a climate colder than the present one. The rubble deposits of the third stage on the north side of Jumbo Dome are cut by gullies which are choked by rubbles of the fourth stage. The absence of any topographic expression of the rubbles of the third stage, such as is characteristic of the rubbles of the fourth and fifth stages, suggests that the former are probably of considerably greater antiquity than the latter.

RUBBLE DEPOSITS OF THE SECOND STAGE

Scattered blocks of andesite forming a thin sheet of rubble cap a ridge of Tertiary rocks that extends north from the prominent point on the northeast corner of Jumbo Dome (fig. 2). This ridge rises about 50 feet above the surrounding valleys, which are filled with rubbles of the third and fourth stages. Between these scattered boulders and the mountain from which they were derived is a stretch of ridge about 2,000 feet long, on which Tertiary sandstone and Paleozoic(?) schist crop out. The boulders have thus been moved 2,000-3,000 feet horizontally on a slope of less than $15^{\circ}$ and presumably are the remains of a formerly more extensive rubble deposit. The scattered boulders were brought to their present position from the mountain on a surface into which stream valleys have been incised at least 50 feet, and probably more. This thin dissected sheet of detritus represents a period of rubble formation much older than the third, fourth, or fifth stage and separated from them by a considerable period of erosion.

Rubbles of andesitic debris, capping the outcrops of Tertiary sandstone exposed in steep-sided badland-like gullies on the southwestern and southeastern corners of Jumbo Dome, are tentatively correlated with the second stage. They are separated in part from their original source (the shoulders of the mountain) by gullies comparable in size to the gullies which dissect the rubble deposits of the second stage on the north side of Jumbo Dome. On the other hand, these second-stage rubbles descended into valleys which had been carved in rubbles remaining from a still earlier stage (first stage). In addition, the second-stage rubbles appear to have been derived, in part, from rubbles of the first stage.

RUBBLE DEPOSITS OF THE FIRST STAGE

Deposits of angular boulders of andesite similar to those which are described above are perched on the ends of spurs extending from Jumbo Dome and on the tops and sides of hills now separated from Jumbo Dome by broad valleys roo feet deep. Some of these deposits are as much as $\mathrm{I} \frac{1}{2}$ miles from Jumbo Dome and must have been transported on a slope of less than $15^{\circ}$. They are remnants of an apron 
of rubble extending from Jumbo Dome. The apron originally must have been so extensive that presumably a vast field of blocks extended from the dome on all sides as far as $\mathrm{I}-2$ miles from the contact between the andesite and sandstone. These rubbles are older than all the others and are assigned to the first stage of rubble formation. Rubbles of the younger stages occupy the valleys which separate these rubble deposits of the first stage from Jumbo Dome. Where firststage rubbles are found on the ends of ridges extending from Jumbo Dome, younger rubbles, having ridden out on these ridges, rest on exposed Tertiary rocks which separate the oldest rubble deposits from their source. This is clearly seen on the ridge that forms the west side of the canyon of Winter Creek (fig. 2). Here rubble deposits of the third and fourth stages rest on Tertiary rocks which form the crest of the ridge. The triangular north slope of this ridge is covered with large angular blocks of andesite which are almost completely buried in the mossy tundra vegetation which covers this ridge. Exposures on the east and west walls of this ridge indicate that these blocks form a veneer over northdipping Tertiary rocks, which, in turn, form a plate about roo-r 50 feet thick, resting on schist.

Similar rubble deposits of coarse angular andesite blocks form the noses of the northwest, west, and southwest shoulders of the mountain. On the ridges behind each of these deposits Tertiary sandstone comes to the surface, and the rubbles are completely dismembered from their source. The canyons between these ridges, which contain rubble deposits of the third and fourth stages, appear to have been cut after the older rubble deposits were formed.

South of Jumbo Dome and north of
Marguerite Creek is a haphazard jumble of irregular hills, in part flat-topped, in part steep-sided and with narrow crests, which are separated largely by undrained depressions, a few of which contain ponds. At first glance this appears to be landslide topography, and the possibility that a large landslide was once precipitated from the south face of Jumbo Dome was considered. However, most of the steep-sided hills consist of Tertiary coal-bearing rocks in place, and the undrained depressions lie in intervening valleys which are choked by rubble of angular andesite blocks. The broader flat-topped hills are covered by a sheet of rubble consisting of andesite blocks and differing in no way from other rubble sheets. From these flat-topped hills streams of blocks extend down the slopes eroded in Tertiary clays and sandstones. These block streams are now completely covered with moss and are therefore ancient. They were not active as late as the time of formation of the rubble deposits of the fifth stage. The explanation invoked to account for this curious assemblage of hills is that a field of rubble once extended from Jumbo Dome as a broad apron covering a gentle surface, which has a present altitude of about 3,000 feet (fig. 5, $A$ ). This apron presumably was formed under the influence of the cold climate of a glacial stage or substage. A period of stream erosion, probably related to a warmer interglacial or interstadial climate, followed the development of this rubble; canyons a few hundred feet deep were cut into it from the south, east, and west. Canyon walls in the soft Tertiary rocks had steep, bare slopes, such as exist in recent badlands formed by tributaries to Lignite Creek, a few miles south. As the streams dissected this rubble apron, isolated steep-sided hills capped with coarse andesite blocks 

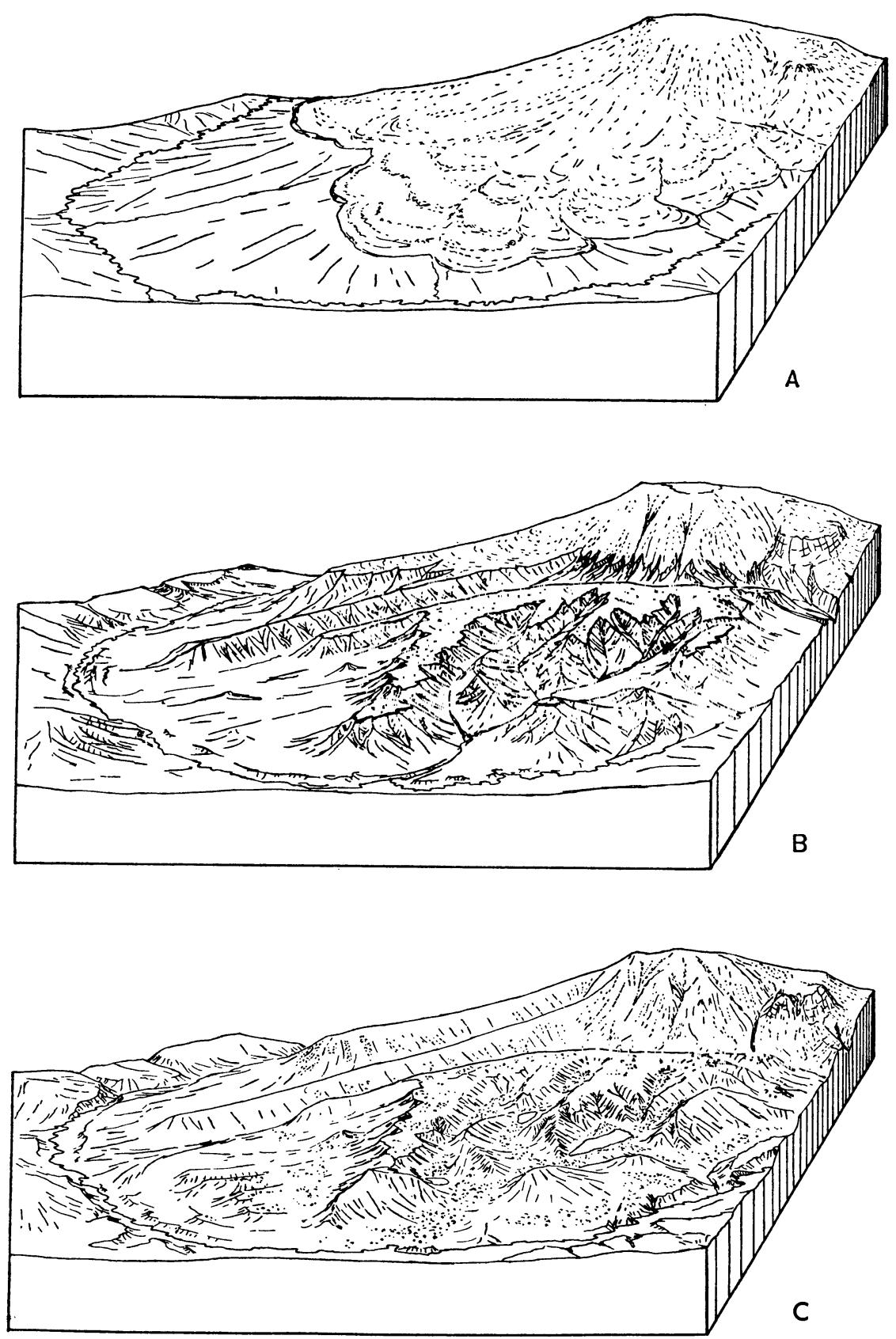

Fig. 5.-Block diagrams representing the development of topography on the south side of Jumbo Dome. $A$, south side of Jumbo Dome at close of first stage of rubble formation. $B$, south side of Jumbo Dome at close of period of badland-forming erosion following the first stage of rubble formation. $C$, present appearance of the south side of Jumbo Dome, after later periods of frost action and rock-glacier movement. 
must have dominated the local topography. The appearance of the area at that time is diagrammatically illustrated in figure $5, B$. Another change in climate brought a return to conditions favoring mass movement of blocky material and unfavorable to canyon-cutting. The masses of angular blocks slid off the hills and into the narrow canyons, filling them to a greater depth in some places than in others and producing a peculiarly haphazard-looking topography, with numerous undrained depressions, which is shown diagrammatically in figure $5, C$.

It is likely that more than one stage of canyon-cutting and hillside-sloughing is involved in the destruction of the original broad apron of rubble. In the short time spent in the area, however, it was not possible to establish criteria for more than one period of stream erosion succeeded by one period of intensive frost action. The history, as represented here and illustrated in figure 5 , is to be regarded as a simplification of a presumably more complex story. This group of hills is separated from Jumbo Dome by a valley into which deposits of rubble, tentatively correlated with the second stage, have spilled. It is therefore older than the second stage and is tentatively correlated with the first stage. Because this broad apron of rubble is closer in altitude to the present stream grade than are other deposits assigned to the first stage, it may represent a separate stage. It was not possible, however, to develop a satisfactory criterion for distinguishing it from other deposits of the first stage; it is therefore grouped with them.

INFLUENCE OF CLIMATE ON DENUDATION IN THE ALASKA RANGE

It has been shown above that the rubble deposits and the detritus-covered surface of Jumbo Dome are, for the most part, inactive and that there probably has been no significant movement of the most recent rubble deposits for at least two hundred years. Such movement as has been observed is related to less rigorous climatic conditions than those which prevailed during the formation of the rubble deposits. Soil features and surface forms of the type described by Högbom (I9I4) and Sharp (I942a), among others, and ascribed by nearly all workers to factors introduced or intensified by cold climates show a strong altitudinal zoning of the lower limits of their present activity on the north side of the Alaska Range. This zoning is related largely to the size and degree of sorting of constituent particles of the soil involved in the movement. In the vicinity of Jumbo Dome, the lower limit of presently active mass movement of debris, consisting predominately of blocks larger than I foot in average diameter, is about $4,600-4,800$ feet (or just above the summit of Jumbo Dome). Polygonal soils in poorly sorted, moderately fine debris are active above an altitude of 2,300 feet, and solifluction or creep is taking place above an altitude of 2,000 feet, beneath moss and tundra cover on some north-facing slopes in exceptionally favorable situations and where underlain by Tertiary sandstone and claystone.

The rapid downslope movement of debris under conditions of rigorous climate results in overloading the streams and causes them to aggrade their beds. This has been recognized by students of the Pleistocene in Germany (Zeuner, I945, pp. 25-27) and in the Middle West (Lueninghoener, 1947). Matthes (1900, pp. I82-I84) reported this effect in the Big Horn Mountains. This phenomenon also is clearly demonstrated in many of the higher, unglaciated parts of the Alaska Range, such as the headwaters of 
the Savage River and of Healy Creek. The constant downslope mass movement tends to fill in gullies as rapidly as they are formed and inhibits many characteristic types of stream erosion, such as badland formation, gullying, etc. The results of such a degradational regime are smooth, featureless hillslopes of large extent, such as are found throughout much of interior Alaska. Only through a climatic amelioration sufficient to slow considerably or completely to stop mass movement of soils can normal stream erosion become dominant. Stream erosion is generally dominant today below an altitude of 4,000 feet. This is amply attested by terrace-cutting, gullying, and badland erosion that are active everywhere below this altitude throughout the north flank of the Alaska Range. Badlands are restricted almost entirely to the Tertiary formations. Bare, actively eroded badlands occupy only a small portion of the surface area on which one would expect to find them in this region. Typical of these is the badland shown in plate 2, $B$; this area is in typical basal Tertiary conglomerate and is located about 4 miles northeast of Jumbo Dome, at an altitude of 2,500 feet. Here active dissection is destroying an older gentle surface (seen in right background) mantled with a layer of solifluction debris Io feet thick. Badland erosion is initiated through landslides which take place during the thawing-out of the upper layer of frozen ground. This lays bare the underlying soft sandstone and shale, which are readily attacked by meltwater in spring and by the runoff of summer thunder showers and autumn rainstorms.

Areas of small hills, of steepness equal to that of the badlands but covered with tundra-type vegetation and possessing rounded tops, are thought to be badlands formed in an earlier cycle of stream erosion and later stabilized through develop- ment of a turf cover during a cold part of the climatic cycle.

It is likely that the upper limit of terracing and badland formation always lies below the lower limit of movement of coarse rock debris, and it probably is as much as 500 or I,000 feet below the lower limit of activity of bouldery rubbles or rock glaciers. It is evident that to bring about conditions for the erosion of rubbles by streams requires raising the isothermal surfaces at least to their present position. It was shown in an earlier part of this paper that the lowest altitude of peaks that have glacier-filled cirques is 7,200 feet and that of peaks bearing cirques of the Wisconsin stage is 6,000 feet. The lowering of isothermal surfaces necessary to produce rock glaciers on Jumbo Dome is, therefore, approximately that required to bring about conditions of the maximum of Wisconsin glaciation. Each period of rock-glacier formation may well represent a period of advance of the glaciers in the mountains corresponding to continental glaciation in other parts of North America. Correspondingly, each period of terrace-cutting, badland erosion, and cessation of activity of the rock glaciers should correspond to an interglacial or interstadial fluctuation of climate in North America.

\section{THE PLEISTOCENE CHRONOLOGY INDI-}

CATED BY THE RUBBLE DEPOSITS OF JUMBO DOME

The evidence of the rubble deposits of Jumbo Dome suggests that the older glaciation which has been recognized in the Alaska Range was followed by at least five episodes of glacial climate, during which the movement of rubble on Jumbo Dome took place. The episodes were separated by intervals of less severe climate, during which the rubble deposits were dissected or otherwise modified. The two earlier of these episodes of gla- 
cial climate (represented by rubble deposits of the first and second periods of rubble movement) were separated from each other, as well as from both the older glaciation and the third period of rubble movement, by relatively long periods of climatic amelioration, during which considerable uplift and dissection took place. The three younger periods of rubble movement were separated from one another and from the present by much shorter periods of climatic amelioration, in which very little dissection and probably little uplift took place.

No attempt is made in this paper to correlate the episodes of rubble movement on Jumbo Dome with the glacial stages and substages of eastern North America. The short amount of time spent on the problem and the uncertainties involved in such a long-range correlation make any such attempt of doubtful validity. More field work in Alaska and in western North America undoubtedly will show that at least some of the periods of glacial climate indicated by the rubble deposits of Jumbo Dome correlate with glacial stages and substages in the United States.

ACKNowledGMENTS.-The manuscript was critically read and edited by Kirk Bryan, of Harvard University, and by Fred H. Moffit, S. R. Capps, and Charles S. Denny, of the United States Geological Survey, who have offered many helpful comments and suggestions. The writer especially wishes to acknowledge his indebtedness to Professor Bryan, without whose instruction these features would have been overlooked in the field. The writer also wishes to acknowledge the kindness of J. D. Henney and Nels Jackson of Ferry, Alaska, in permitting the use of. their cabins. George C. Turner and Harrel C. Stacy were field assistants during the field season of 1947, when the area was mapped. W. S. Benninghoff, botanist, of the Geological Survey visited the area with the writer on September $17-20$, 1948 .

\section{REFERENCES CITED}

ANDERsson, J. G. (Igo6) Solifluction, a component of subaerial denudation: Jour. Geology, vol. I4, pp. 9I-II 2.

BRETZ, J H. (1935) Physiographic studies in East Greenland: the fiord region of East Greenland: Am. Geog. Soc. Special Pub. I8.

CAPpS, S. R. (rgro) Rock glaciers in Alaska: Jour. Geology, vol. I8, pp. 359-375.

- (1912) The Bonnifield region, Alaska: U.S. Geol. Survey Bull. 5or.

- (I93I) Glaciation in Alaska: U.S. Geol. Survey Prof. Paper I 70-A.

(1932) Eastern portion of Mount McKinley National Park: U.S. Geol. Survey Bull. 836-D, pp. 219-300.

(I940) Geology of the Alaska Railroad region: U.S. Geol. Survey Bull. $9 \circ 7$.

Chaix, André (1923) Les Coulées de blocs du Parc National Suisse d'Engadine (note préliminaire): Le Globe (Organ de la Soc. géographie de Genève), vol. 62 , pp. I- 38 .

HÖGBOM, BERTIL (I9I4) Ửber die geologische Bedeutung des Frostes: Upsala Univ., Geol. Inst., Bull. I 2, pp. 257-384.

Howe, ERNEST (I909) Landslides in the San Juan Mountains, Colorado: U.S. Geol. Survey Prof. Paper 67.

Kesseli, J. E. (I94I) Rock streams in the Sierra Nevada, California: Geog. Rev., vol. 3I, pp. 203-227.
Lueninghoener, G. S. (1947) The post-Kansan geologic history of the lower Platte River valley: Univ. Nebraska Studies, new ser., no. 2.

Matthes, F. E. (1900) Glacial sculpture of the Big Horn Mountains: U.S. Geol. Survey 2rst Ann. Rept., pt. 2, pp. I67-I9o.

- (I930) Geologic history of Yosemite Valley: U.S. Geol. Survey Prof. Paper I60.

Mofrit, F. H., and CAPPS, S. R. (IgII) Geology and mineral resources of the Nizina district, Alaska: U.S. Geol. Survey Bull. 448.

Patron, H. B. (I910) Rock streams of Veta Peak, Colorado: Geol. Soc. America Bull. 21, pp. 663676.

Sharp, R. P. (I942a) Mudflow levees: Jour. Geomorphology, vol. 5, pp. 222-227.

$(1942 b)$ Soil structures in the Saint Elias Range, Yukon Territory: ibid., pp. 275-282.

TyrReLL, J. B. (I9IO) "Rock glaciers" or chrystocrenes: Jour. Geology, vol. 18, pp. 544-553.

Wahrhaftrg, Clyde (I946) Preliminary report on the physiographic history of part of the Alaska Range (abstr.): Washington Acad. Sci. Jour., vol. 36, pp. 134-1 35 .

WASHBURN, A. L. (1947) Reconnaissance geology of portions of Victoria Island and adjacent regions, arctic Canada: Geol. Soc. America Mem. 22.

Zeuner, F. E. (1945) The Pleistocene period, its climate, chronology, and faunal succession, London, The Ray Society. 